\title{
Identification on Residential Park Facilities Criteria Based on Visitor's Perception
}

\author{
Achmad Ridwan Lubis, Dewi Septanti, and Sarah Cahyadini \\ Department of Architecture, Institut Teknologi Sepuluh Nopember, Surabaya \\ e-mail: ridon02@gmail.com
}

\begin{abstract}
Abstrak-The soaring number of urban population and the rising of it from time to time will implicate on the pressure of the utilization of city spaces especially residential area, public and social facility also public open spaces in the city. The elevating development of residential area is not only causing the widening of built up land but also decreasing the availability of open spaces. In eastern Surabaya as one of the residential area development location has variety of activity in utilizing a housing scale of green open spaces. Furthermore, the efforts in optimizing parks around eastern Surabaya that can be used as public and social spaces. Citizen's participation to fulfill those efforts are crucial as the perception influence the need of residential parks as a facility. Therefore, concept of providing facilities on the residential parks through the citizen's perception needs to be acknowledge. The purpose of this research is to identify the criteria of facility on the parks based on the citizen's perception. The step in this research, is to identify the residential park facility's criteria based on the visitor's perception. To find the answer, quantitative methods is used in this research. Descriptive statistic is used to answer the target of the research. According to the analysis's results, the criteria of the preferred facility on the residential parks around eastern Surabaya with the highest frequency are trash bin, lights, park benches, shades, pedestrians' side, children's playground, public toilet, security guards' post, easy accessibility, sports field, jogging track, vegetation's variety and parking spots. Meanwhile, the non-preferred facilities are the ornament for the aesthetic like statues, water fountains, internet access, ready to drink water stations, signs, and gazebos.
\end{abstract}

Kata Kunci-Citizen's Perpection, Green Open Spaces, Park's Facilities, Residential Park.

\section{INTRODUCTION}

G REEN open space is a part of open space which is filled by plants, greens, and vegetation to support direct and indirect benefit provided by the particular green open space which are safety, comfort, prosperity, and aesthetic of the area around the green open space, and the high number of residential area development was causing the widening of built-up land and the narrowing of available open spaces [1]. The open space within the residential area was designed and used for recreational activity, and physical exercise which function as services for lots of resident around the more localized part of the city like, district and neighborhood [2]. Specifically, open spaces play part in providing different function and service like entertainment, social interaction, nature exposure and sense of community [3]. Green open space as media for utilizing activity is highly needed by the community as a place for having activity, and socializing with others [4]. The tendency that happened in the residential area lately is to revert the residential area back to the balance
Tabel 1

Respondent Amount

\begin{tabular}{lcc}
\hline \hline Responden's Age & Amount & Persentage \\
\hline 12-16 years & 1 & $0,96 \%$ \\
17-25 years & 14 & $13,46 \%$ \\
26-35 years & 32 & $30,76 \%$ \\
36-45 years & 38 & $36,53 \%$ \\
46-55 years & 14 & $13,46 \%$ \\
$56-65$ years & 4 & $3,84 \%$ \\
66 years $<$ & 1 & $0,96 \%$ \\
\hline \multicolumn{1}{c}{ Total } & $\mathbf{1 0 0}$ & $\mathbf{1 0 0 \%}$ \\
\hline \hline
\end{tabular}

between green open space and built-up land or non-green open space so that a livable proper environment which are healthy and comfortable can be achieved [5].

The user's role, visitors or resident for the best development of green open space is significantly needed and the design for pubilc open space has to consider the user's factor and activity [6]. One of the needed role in the context of environmental design is perception. The aspect of environmental perception is vital because of the decision or chociecs for the development will be determined by the desaigner's perception of environment [7].

This study is focusing on the identification on residential park facilities criteria based on visitor's perception to support the mean of social activity and aesthetic as the mean of recreational activity, education or other activity based on the visitor's perception.

Based on the research of the public spaces' elements which have to be available within the residential park are pedestrian lane's light, main street's light, bus stops, signs, phone booth, garbage bins, vegetation, and clean water/toilets [8]. Meanwhile, there were other research which stated that facilities that had to be available were parking spots, plaza, playgrouind, physical exercise's facility, jogging track, gazebos, benches, public toilet and vegetation [9].

\section{RESEARCH METHOD}

Paradigm is a way of perspecting, understanding, interpreting, a framework of thoughts, a belief which gives instruction to the action. To achieve that particular goal, this research used a postpositivist paradigm. Postpositivist paradigm sees the phenomenon on the field by emphasizing on the observation's result and interviewing users on the commercial site of the city which has a lot of individual 
The $6^{\text {th }}$ International Seminar on Science and Technology (ISST) 2020

July $25^{\text {th }} 2020$, Institut Teknologi Sepuluh Nopember, Surabaya, Indonesia

Tabel 2.

Frequency Table Of The Park's Facility Choices

\begin{tabular}{|c|c|c|c|c|c|c|c|}
\hline \multirow[t]{2}{*}{ Variable } & \multicolumn{7}{|c|}{ Respondents' Age } \\
\hline & $\begin{array}{c}\text { Early } \\
\text { Teenagers }\end{array}$ & $\begin{array}{c}\text { Late } \\
\text { Teenagers }\end{array}$ & Early Adult & Late Adult & Early Elderly & Early Elderly & Old People \\
\hline V1 & $\mathrm{N}$ & $\mathrm{SP}$ & $\mathrm{P}$ & $\mathrm{P}$ & $\mathrm{P}$ & SP & $\mathrm{N}$ \\
\hline V2 & $\mathrm{P}$ & SP & $\mathrm{P}$ & SP & SP & SP & $\mathrm{P}$ \\
\hline V3 & P & SP & SP & SP & SP & SP & SP \\
\hline V4 & SP & SP & SP & SP & SP & SP & SP \\
\hline V5 & $\mathrm{P}$ & SP & SP & SP & SP & SP & SP \\
\hline V6 & TP & TP & TP & TP & N/TP & TP & $\mathrm{P}$ \\
\hline V7 & $\mathrm{P}$ & TP & $\mathrm{P}$ & $\mathrm{P}$ & $\mathrm{P}$ & $\mathrm{N}$ & $\mathrm{P}$ \\
\hline V8 & SP & SP & SP & SP & SP & SP & $\mathrm{P}$ \\
\hline V9 & $\mathrm{N}$ & SP & $P$ & SP & SP & $\mathrm{P}$ & SP \\
\hline V10 & SP & SP & $\mathrm{P}$ & SP & SP & $\mathrm{P}$ & $\mathrm{P}$ \\
\hline V11 & SP & $\mathrm{P}$ & $P$ & $\mathrm{P}$ & $\mathrm{P}$ & $\mathrm{P}$ & $P$ \\
\hline V12 & SP & SP & $\mathrm{P}$ & $\mathrm{P}$ & SP & $\mathrm{P}$ & $\mathrm{P}$ \\
\hline V13 & $P$ & SP & $\mathrm{P}$ & SP & SP & $\mathrm{P}$ & SP \\
\hline V14 & $\mathrm{P}$ & $P$ & SP & SP & SP & SP & SP \\
\hline V15 & $P$ & SP & $P$ & SP & $\mathrm{P}$ & $\mathrm{P}$ & $\mathrm{P}$ \\
\hline V16 & TP & TP & $P$ & $P$ & $\mathrm{P}$ & $\mathrm{P}$ & SP \\
\hline V17 & $\mathrm{P}$ & SP & SP & $\mathrm{P}$ & $\mathrm{P}$ & $\mathrm{P}$ & SP \\
\hline V18 & TP & $\mathrm{N}$ & TP & N/TP & $\mathrm{P}$ & N/TP & $\mathrm{N}$ \\
\hline V19 & $\mathrm{N}$ & $\mathrm{N}$ & TP & $\mathrm{N}$ & $\mathrm{N}$ & $\mathrm{N}$ & $\mathrm{N}$ \\
\hline
\end{tabular}

Notes :

V1 : Vegetation

V2: Park benches

V3 : Lights

V4 : Garbage bins

V5 : Public toilet

V6 : Internet connection

V7 : Drinkable water

TP : Not important

SP : Very important

V8 : Shades
V9 : Security posts
V10 : Kid's playground
V11 : Jogging Track
V12: Sports field
V13: Gazebos
V14 : Pedestrian's lane
N $:$ Neutral
STP : very not important

V8 : Shades

V10 : Kid's playgroun

V11 : Jogging Track

V12 : Sports field

STP : very not important

\author{
V15 : Accesibility \\ V16: Signs \\ V17 : Parking spots \\ V18: Statues \\ V19: Water fountain \\ N/TP : Neutral not important \\ N/P : Neutral and important \\ $\mathrm{P}$ : Important
}

interaction or group interaction outdoor or based on objectivity [10].

\section{A. Research Strategy}

This study used a quantitative analyzing technique which was descriptive statistic. The data collection was conducted by using a Likert scale questionnaire. a Likert scale questionnaire was given to respondents which were visiting the park with the hope for respondents to sahre their perspective toward the facility that had to be available in the residential park. Data were obtained from 20 research's locations (100 respondents). Variables in this study were, vegetation, park benches, lights, garbage bins, public toilets, internet connection, drinking water, shades, park security posts, jogging track, sports arena, gazeboz, pedestrian's lane, easy accesibility, signs, parking spots, statues and water fountain.

\section{ANALYSIS RESULT}

To answer the target, this research used SPSS 23 with the Frequesncy Descriptive analysis type. To ease the data processing of identification on residential park facilities criteria based on perception within the SPSS 23, a simplification was done on the age variable of the respondent's characterics which was simplified based one of the $2009^{\text {th }}$ regulation of the Health Department of Indonesian republic which are for age $0-5$ year old (toddler), $5-11$ year old (kids), $12-16$ year old (early teeanger), $17-25$ year old (late teenager), 26 - 35 year old (early adult), 36 - 45 year old (late adult), 46 - 55 (early elderly), 56 - 65 year old (late elderly), above 65 year old (old people). Respondent amount and frequency table of the park facility choices can see Table 1 and Table 2.

Based on the data processing result of residetial park facilities criteria for the early teenager age category toward the park facility's variable, respondents were long for facilities like park benches, lights, garbage bins, public toilet,drinkable water station, shades, kid's playground, jogging track, sports field, pedestrian's lane, easy accessibility, and parking spots for the park.

Based on the data processing result of residetial park facilities criteria for the early adult age category toward the park facility's variable, respondents were long for facilities like variety of vegetation, park benches, lights, garbage bins, internet connection, drinkable water station, shades, kids' playground, jogging track, sports field, easy accesibility, parking spots, and statues for the park.

Based on the data processing result of residetial park facilities criteria for the late adult age category toward the park facility's variable, respondents were long for facilities like variety of vegetation, park benches, lights, garbage bins, public toilets, shades, security posts, kids' playground, jogging track, sports field, gazebos, pedestrians' lane, easy accesibility, parking spots for the park.

Based on the data processing result of residetial park facilities criteria for the late adult age category toward the park facility's variable, respondents were long for facilities like variety of vegetation, park benches, lights, garbage bins, public toilets, shades, security posts, kids' playground, 
The $6^{\text {th }}$ International Seminar on Science and Technology (ISST) 2020

July $25^{\text {th }} 2020$, Institut Teknologi Sepuluh Nopember, Surabaya, Indonesia

jogging track, sports field, gazebos, pedestrians’ lane, easy accesibility, parking spots for the park.

Based on the data processing result of residetial park facilities criteria for the early elderly age category toward the park facility's variable, respondents were long for facilities like variety of vegetation, park benches, garbage bins, public toilets, drinkable water station, shades, security posts, kids' playground, jogging track, sports field, gazebos, pedestrians' lane easy accesibility, signs, and parking spots for the park.

Based on the data processing result of residetial park facilities criteria for the late elderly age category toward the park facility's variable, respondents were long for facilities like variety of vegetation, park benches, lights, garbage bins, public toilets, shades, security posts, kids' playground, jogging track, sports field, gazebos, pedestrians' lane, easy accesibility, signs, and parking spots were the most wanted facilities for the park.

Based on the data processing result of residetial park facilities criteria for the very old people age category toward the park facility's variable, respondents were long for facilities like park benches, lights, garbage bins, public toilets, shades, internet connection, drinking water station, security posts, kids' playground, jogging track, sports field, gazebos, pedestirans' lane, easy accesibility, signs, parking spots for the park.

\section{CONCLUSION}

According to the data analysis' result, the most preferred facilities by the eastern Surabaya's citizens were garbage bins, lights, benches, shades, pedestrians' lane, kids' playground, public toilets, security posts, easy accessibility, sports field, jogging track, variety of vegetation, and parking spots. On the contrary, facilities which were not preferred were, aesthetics like statues, water fountain, internet connection, drinkable water station, signs, and gazebos.

\section{REFERENCES}

[1] C. D. Maarebia, "Identifikasi Ruang Terbuka Hijau Di Kawasan Perumahan Griya Piniki Indah Kecamatan Mapanget Kota Manado," Jurnal Ilmilah Fakultas Pertanian Universitas Sam Ratulangi Vol I No 6, pp. 1-9, 2017.

[2] B. W. Stanley, "Urban Open Spaces in Historical Perspective: A Transdisciplinary Typology and Analysis," Journal of Urban Geography, pp. 1089-1117, 2013.

[3] D. T. Do, Y. Cheng, A. Sijau and Y. Chen, "Public Park Behaviour In Da Nang: An Investigation Into How Open Space Is Used," Frontiers of Architecture Research Vol 8, pp. 454-470, 2019.

[4] L. Mawardah, "Interaksi Taman dan Kampung Sebagai Simbol Kota Humanis (Studi Kasus: Taman Kunang-Kunang, Penjaringan Sari, Surabaya)," Seminar Nasional Universitas Sebelas Maret Surakarta, pp. 23-30, 2014

[5] C. Christianingrum, Perencanaan Ruang Terbuka Hijau Di Kawasan Komplek Perumahan "Galmas Residence", Surakarta: Universitas Sebelas Maret, 2011.

[6] S. Permana, Tipologi dan Karakteristik Pemanfaatan Ruang Terbuka Non Hijau Skala Kota di Kota Bandung, Bandung: Institut Teknologi Bandung, 2011.

[7] Rapoport, The Use and Design of Open Space in Urban Neighborhoods, Berlin: Walter de Gruiter and Co, 1986.

[8] M. R. Azzaki, "Persepsi Masyarakat Terhadap Aktivitas Ruang Terbuka Publik Di Lapangan Pancasila," Jurnal Ruang, pp. 231-240, 2013.

[9] Nurbalqis, "Arahan Perancangan Taman Kota Sebagai Pemenuhan Kebutuhan Ruang Publik Di Kecamatan Kota Juang," Jurnal Ruang, pp. 1-9, 2015.

[10] R. Lucas, Research Methods For Architecture, United Kingdom: Laurence King Publishing Ltd, 2016. 